\title{
Acyl lipids in the supramolecular chlorophyll-protein complexes of photosystems - isolation artifacts or integral components regulating their structure and functions?
}

ZBIGNIEW KRUPA

Department of Plant Physiology, Maria Curie-Skłodowska University, Akademicka 19, 20-033

Lublin, Poland

(Received: March 15,1988. Accepted: March 31,1988)

\begin{abstract}
The precise nature of interactions between the chloropnyll-protein complexes related to photosystem I or photosystem II and the acyl lipids in the thylakoid membranes is not yet fully elucidated. Analyses of the lipid content of isolated photosystem supramolecular complexes reveal that they are integral components of these complexes. However, the relations between certain acyl lipids and the specific structure and functions of the complexes investigated are still widely discussed. The most generally accepted phenomenon is the fact of participation of phosphatidylglycerol containing the unique trans- $\Delta^{3}$ -hexadecenoic acid in the oligomerization of the light-harvesting chlorophyll $a / b$ protein complex II.
\end{abstract}

Key words: acyl lipids, chlorophyll-protein complexes, photosystems, thylakoid membranes

\section{INTRODUCTION}

Photosynthesis in green plants is carried out by a highly organized system of the thylakoid membranes. These membranes may be described in terms of a mosaic model with integral globular proteins being dispersed in a fluid lipid matrix. The proteins constitute about $60 \%$ of the membrane material while the acyl lipids and pigments account for the remaining $40 \%$. The majority of the membrane proteins consist of four types of chlorophyll-protein complexes, i.e. the photochemically active chlorophyll a-proteins containing photocenters I or II surrounded by antennae chlorophyll and photochemically inactive 
light-harvesting chlorophyll a/b protein complexes I and II. It is now clearly established that all chlorophyll and carotenoids in the thylakoids of higher plants are non-covalently bound to proteins associated in the supramolecular complexes mentioned above.

The refinement of solubilization and analysis techniques has allowed for the extraction of these supramolecular complexes closer to the "in vivo" state. Progress in the analysis of chl-protein complexes in the last decade has resulted in accumulation of evidence indicating the presence of acyl lipids as an integral constituent of these complexes and suggesting their indispensability for proper structural organization and function. Much evidence concerning some aspects of the involvement of acyl lipids in the structure and function of thylakoid membranes has recently been summarized by Rawyler and Siegenthaler (1986) and the reader is kindly advised to consult that volume.

\section{PHOTOSYSTEM I}

About $85 \%$ of PSI complexes are located in unstacked regions of grana (stroma thylakoids). The PSI particles contain the so-called "core complex I" which is functionally competent and to which specific light-harvesting $\mathrm{a} / \mathrm{b}$ protein antenna complexes I (LHCIa and LHCIb) are bound. A number of methods for isolation and purification of the PSI complex have been published. Depending on the principle of the method they can be divided into two groups. The methods utilizing non-denaturating polyacrylamide gel electrophoresis of the thylakoid membranes gently solubilized with detergents (sodium or lithium dodecyl sulfate, sodium deoxycholate, octyl glucoside, Triton X-100) result in the resolution of different chl-protein complexes, among them CP1a (oligomer) and CP1 (monomer) which are related to the reaction centre of PSI (Hayden and Hopkins 1977, Waldron and Anderson 1979, Camm and Green 1980, Henry and Siegenthaler 1981, Picaud et al. 1982, Noben et al. 1983, Vierling and Alberte 1983, Huner et al. 1987a). The methods of the second group are based upon solubilization of the thylakoid membranes with Triton X-100, separation of the extract during sucrose gradient centrifugation in the presence of low concentrations of Triton X-100, resulting in purified PSI particles retaining their LHC's. These particles usually exhibit a chlorophyll to P700 ratio of 110-200 and contain 11-13 polypeptides related to the reaction centre and antenna complexes. The widely accepted model of this method (Mullet et al. 1980a, b) is sometimes modified by adding some extra procedures allowing better characterization of the properties of these particles and their constituents (Bassi and Simpson 1987). It should be underlined that PSI particles obtained by these procedures have the same properties as a high-molecular mass complex CP1a resolved by non-denaturing gel electrophoresis. Detailed descriptions of the structure and function of PSI complexes have been published recently (Staehelin 1986, Thornber 1986, and refs. therein). 
Although the acyl lipid composition of the thylakoid membranes is very well known, the question whether these lipids are the integral constituents of chl-protein complexes and not artifacts created by the isolation and purification of the complexes from thylakoid membranes and whether they play a role in the structure and functions of these complexes, still remains open. Thus, considerations concerning this problem should start from the qualitative and quantitative composition of acyl lipids in the thylakoid membranes. Table 1 shows the average acyl lipid content in the thylakoid membranes isolated

\section{Table 1}

The average acyl lipid content in the thylakoid membranes isolated from different plants

\begin{tabular}{|c|c|}
\hline Acyl lipid & $\begin{array}{c}\text { Average value } \\
\text { (mean } \pm \text { SD) }\end{array}$ \\
\hline MGDG & $47.1 \pm 4.7$ \\
DGDG & $30.2 \pm 4.6$ \\
SQDG & $8.0 \pm 2.8$ \\
PG & $10.9 \pm 2.7$ \\
PC & $3.8 \pm 1.1$ \\
\hline
\end{tabular}

The results for calculations were taken from:

Chapman et al. 1984 (Amaranthus retroflexus. Poa annua, Senecio vulgaris),

Gounaris et al. 1983, 1984a (spinach),

Guillot-Salomon et al. 1982 (pea, barley),

Henry et al. 1984 (barley),

Huner et al. 1987a (rye),

Krupa 1982 (bean),

Krupa 1988 (radish cotyledons),

Krupa and Baszyński 1985 (tomato),

Murphy and Woodrow 1984 (spinach),

Rawyler and Siegenthaler 1981a (spinach),

Tuquet et al. 1984 (spinach).

from different plants. This will be the starting point to determine to what extent the content of acyl lipids is unique for PSI or other complexes discussed in this article. Unfortunately, it has not yet become a common practise to analyse the lipid composition of chl-protein complexes isolated by different methods and from different sources. Table 2 summarizes such results obtained for PSI complexes during the last decade. It should be underlined that although sometimes a relative percentage of each acyl lipid in the total content is similar to that in whole thylakoids, their amounts are usually more than several times lower because of the isolation procedures removing, as is supposed, all lipids forming the bilayer structure of the membrane. Thus, the acyl lipids reported here may be considered as integral constituents of these complexes. The method used and the kind of detergent employed are largely responsible for some differences in the lipid compositions showed in Table 2. 
Table 2

A comparison of the acyl lipid composition of PSI supramolecular complexes isolated by various methods

\begin{tabular}{|r|c|c|c|c|c|c|c|c|c|c|}
\hline Acyl lipid & \multicolumn{10}{|c|}{$\%$ Of total content } \\
\hline MGDG & - & 45.0 & 57.2 & 12.5 & 46.2 & 56.1 & 50.4 & 41.0 & 34.8 & 34.0 \\
DGDG & - & 27.0 & 21.4 & 21.9 & 27.1 & 23.7 & 25.9 & 28.6 & 13.0 & 25.2 \\
SQDG & 72.8 & $23.0^{*}$ & - & $34.4^{*}$ & 7.0 & 5.7 & 5.9 & 23.1 & 39.1 & 13.4 \\
PG & - & 5.0 & 14.3 & 31.3 & 13.1 & 9.4 & 10.5 & 5.3 & 8.7 & 13.3 \\
PC & - & - & 7.1 & - & 6.6 & 5.2 & 7.3 & 2.0 & 4.3 & 14.0 \\
PI & 27.8 & - & - & - & - & - & - & - & - & - \\
\hline Source & spinach & tobacco & tobacco & pea & pea & pea & barley & barley & tobacco & spinach \\
& $(1)$ & $(2)$ & $(3)$ & $(4)$ & $(4)$ & $(4)$ & $(4)$ & $(4)$ & $(5)$ & $(6)$ \\
\hline
\end{tabular}

* SQDG + PC

(1) - Rawyler et al. 1980

$(2,3)$ - Tremolieres et al. 1981, 1982,

(4) - Guillot-Salomon et al. 1982,

(5) - Remy et al. 1982,

(6) - Tuquet et al. 1984.

As can be easily calculated, the chl-protein complexes of the reaction centers of PSI or PSI particles are on the whole relatively enriched with sulfolipid (SQDG) and to some extent with phosphatidylglycerol (PG). The relative proportions of monogalactolipid (MGDG) and digalactolipid (DGDG) are lower than those in whole thylakoid membranes. The participation of SQDG in the structure and function of PSI was postulated by Krupa and Baszyński (1977) in their extraction-reconstitution studies on thylakoid membranes and by Menke and his group (Radunz and Berzborn 1970, Menke et al. 1976, Schmid et al. 1978, Radunz et al. 1984a) on the basis of immunological studies on the localization and function of sulfolipid in thylakoids. This could be achieved by the conformational changes caused by SQDG in certain PSI polypeptides. The presence of SQDG as the major lipid class in PSI particles was shown by Rawyler et al. (1980) although the accompanying high amounts of phosphatidylinositol (PI) in these particles are somewhat confusing because this lipid is detected in very low amounts in thylakoid membranes and it is not even widely recognized as an integral component of these membranes. The role of certain membrane acyl lipids in the structure and function of PSI has been postulated by Krupa $(1983,1984 a$, b) on the basis of the effect of some lipolytic enzymes (phospholipases $A_{2}, C, D$, galactolipase) on the polypeptide patterns and chl-protein complexes of enzyme-treated thylakoids. These studies resulted in the proposed array of indispensable acyl lipids for the integrity and stability of chl-protein complexes of photosystem I:

$$
\mathrm{CP} 1 \mathrm{a}+\mathrm{CP} 1-\mathrm{MGDG}>\mathrm{DGDG}>\mathrm{PG}>\mathrm{PC} .
$$

These results confirmed, in fact, the earlier studies carried out in our laboratory, pointing out the role of galactolipids in PSI activity in 
heptane-extracted thylakoids (Krupa and Baszyński 1975). During aging in vitro of purified thylakoid membranes a considerable decrease in DGDG content (and also in that of PG and SQDG) was followed by the decomposition of CP1a - the oligomeric form of CP1 (Hen ry et al. 1982). In a series of elegant and well documented papers originating from Siegenthaler's group it was clearly shown that MGDG and PG are mainly distributed in the outer leaflet of the thylakoid membrane, being thus closely associated with PSI particles (Rawyler and Siegenthaler 1980, 1984, 1985, Siegenthaler 1982, Giroud and Siegenthaler 1984, Siegenthaler and Giroud 1986, Rawyler et al. 1987). A certain specific pool of PG molecules may also be involved in the non-cyciic electron flow from $\mathrm{H}_{2} \mathrm{O}$ to $\mathrm{NADP}^{+}(\mathrm{R}$ awyler and Siegenthaler 1981a, b, Siegenthaler et al. 1987). From these papers, albeit indirectly, one can assume the importance of certain acyl lipid domains for the functioning of PSI particles. A conclusion about the molecular interactions between the photosynthetically active proteins of photosystem I and MGDG and PG has already been drawn from the serological studies on the function of galacto- and phospholipids in the thylakoid membrane (Radunz 1984, Radunz et al. 1984b).

The opinion that galactolipids might not be fixed to a certain chl-protein complex and specific associations between endogenous galactolipids and chl-protein complexes are not evident (Heinz and Siefermann-Harms 1981) seems to be rather irrelevant. However, it must be honestly emphasized that all the evidence concerning the role of certain acyl lipids in the structure and function of PSI complex has come rather from indirect studies. No reports have yet been published dealing with isolated and purified PSI particles and the effect of their acyl lipid composition or its changes on the structure-function relations.

\section{PHOTOSYSTEM II}

Photosystem II domains in thylakoid membranes are composed of the so-called "core-complex" containing the reaction center. The polypeptides of the water splitting system and light-harvesting chlorophyll $\mathrm{a} / \mathrm{b}$ protein complex II (LHCII) being primarily the energetic antenna for PSII and containing about half of the total chlorophyll of photosystems, are attached to the "core complex". Because the PSII reaction centre can be easily separated from its light-harvesting system and characterized separately, this chapter will be divided into two parts discussing the role of acyl lipids in that reaction centre as well as in its LHCII.

CORE COMPLEX II

The PSII core complex can be isolated from thylakoid membranes by different modifications of non-denaturating gel electrophoresis ( $\mathrm{CPa}$ complex), as was discussed in Chapter 2 of this review, or by specialized methods of extraction using different detergents (Triton X-100, digitonin, octyl glucoside), 
followed by sucrose gradient centrifugation, Sepharose or DEAE cellulose columns, isoelectrofocusing (S a to h 1979a, Berthold et al. 1981, Lam et al. 1984, Gounaris and Barber 1985, Ikeuchi et al. 1985, Satoh et al. 1985, Ghanotakis and Yocum 1986). Usually such highly purified preparations contain 5 polypeptides of apparent molecular weights $47,43,33,30$ and $10 \mathrm{kD}$, chlorophyll $\mathrm{a}$, some amounts of chlorophyll $\mathrm{b}, \beta$-carotene, pheophytin, plastoquinone-9 and, depending on the method of isolation and purity of the preparations, some amounts of acyl lipids (e. g. Gou naris and Barber 1985).

The acyl lipid compositions of PSII particles, reaction centers or $\mathrm{CPa}$ complexes have very rarely been investigated. The results of these investigations summarized in Table 3 show that SQDG, besides MGDG, may be

Table 3

A comparison of the acyl lipid composition of PSII supramolecular complexes isolated by various methods

\begin{tabular}{|c|c|c|c|c|c|c|}
\hline Acyl lipid & \multicolumn{7}{|c|}{$\%$ Of total content } \\
\hline MGDG & 70.0 & 14.0 & 34.9 & 39.7 & 54.0 & 29.7 \\
DGDG & 10.0 & 5.0 & 6.7 & 29.1 & 23.0 & - \\
SQDG & - & 50.0 & 16.4 & 8.7 & 5.0 & 70.3 \\
PG & - & 10.0 & 27.2 & 15.7 & 7.0 & - \\
PC & 20.0 & - & 14.9 & 6.8 & 12.0 & - \\
\hline Source & tobacco & tobacco & spinach & spinach & Senecio & spinach \\
& & $(1)$ & $(3,4)$ & $(5)$ & vulgaris & $(6)$ \\
& & & & & $(7)$ \\
\hline
\end{tabular}

(1) - Tremolieres et al. 1982,

(2) - Remy et al. 1982,

(3. 4) - Gounaris et al. 1983, 1984a,

(5) - Tuquet et al. 1984,

(6) - Chapman et al. 1984,

(7) - Gounaris and Barber 1985

recognized as the major acyl lipid component of the PSII reaction centre. The relative amount of PC is also considerably higher than that in whole thylakoid membranes, while that of DGDG is much lower. How can this data be interpreted? Unfortunately, the situation is very similar to the investigations on PSI particles reported earlier in this review. The lack of direct evidence of the participation of some acyl lipids in the structure and function of the PSII reaction centre allows us to draw only rough conclusions from the available data. Let us start our considerations from PC - the acyl lipid which is most frequently referred to PSII. In the opinion of Siegenthaler and his coworkers $\mathrm{PC}$ is the main lipid associated with the thylakoid structures responsible for PSII activity (R awyler and Siegenthaler 1980, 1981b, Siegenthaler et al. 1987). Radunz (1980, 1981, 1984) in his serological investigations on the distribution and function of phospholipids found that in normally functioning thylakoid membranes PC can be a component of the active PSII. A number of 
papers (Murphy 1984, Murphy and Knowles 1984, Murphy and Woodrow 1984) discussed an important functional role of PC as the lipid environment in PSII electron transport and energy transfer to PSI. The role of certain acyl lipids such as PC and DGDG in optimisation of the tertiary organisation of PSII proteins leading to maximal activity of this photosystem has been underlined by Gounaris et al. $(1983,1984 a$, b). The necessity of PC and some other acyl lipids for the integrity of the $\mathrm{CPa}$ complex related to the reaction centre of PSII has been extensively investigated by Krupa (1983, $1984 a, b)$ using a number of lipolytic enzymes such as phospholipase $A_{2}, C, D$ and galaciolipase. The conclusions drawn from these studies showed that the importance of acyl lipids for the integrity and functional stability of $\mathrm{CPa}$ complex could be presented as follows:

\section{$\mathrm{CPa}-\mathrm{PC}>\mathrm{MGDG}>\mathrm{DGDG}>\mathrm{PG}$.}

In 1985 Gounaris and Barber reported the isolation and purification of the lipoprotein complex being the photochemically active reaction centre complex of PSII. Only two acyl lipids were present in this complex - MGDG and SQDG, the former being relatively more abundant. Both lipid classes in the PSII reaction centre were of a very low degree of unsaturation as compared with their counterparts in the thylakoid membranes or PSII membrane preparations. The sufficiently low levels of acyl lipids co-purifying with the complex and a lipid composition very uncharacteristic for the bilayer distinctly indicate that the PSII reaction centre is a lipoprotein-pigment complex. Whether specific types of bonds exist between these lipids and the protein is not definitely known at present. According to Chapman et al. (1984) and Tho mas et al. (1984) a significant part of the total thylakoid MGDG is in vivo concentrated in the lipid matrix around PSII and may be involved in the packaging of this photosynthetic reaction centre into the thylakoid membrane and its correct supramolecular organization. Some attention should be drawn to the role of SQDG in the PSII reaction centre. As can be seen from Table 3 its relative amounts in this supramolecular complex are considerably higher than in thylakoids (compare Table 1). SQDG was postulated earlier (Anderson 1975) to be, together with PG, the predominant specific externally located boundary lipid of chl-protein complex II. Unitt and Harwood (1982) suggested the localization of SQDG in the inner leaflet of the thylakoid membrane, thus closer to PSII. Radunz's recent experiments with antisera against SQDG have endorsed the indirect involvement of this lipid in PSII activity ( $\mathrm{R} \mathrm{a} \mathrm{dunz}$ et al. 1984a). It participates in the conformational changes of proteins involved in the electron transport reactions.

Recently, some attempts have also been made to connect the PG containing trans $-\Delta^{3}$-hexadecenoic acid with the $\mathrm{O}_{2}$ evolution in PSII using phospholipase $\mathrm{A}_{2}$ (Tuquet et al. 1984) but the concomitant hydrolysis of the total PC pool in isolated PSII particles brings in question the final conclusion about the involvement of PG in the oxygen evolution activity. Moreover, Goun aris et al. (1983, 1984a, b) showed that PG and SQDG added to isolated PSII particles completely inhibited the $\mathrm{O}_{2}$ evolving system. 
Light-harvesting chlorophyll $\mathrm{a} / \mathrm{b}$ protein complex II (LHCII) is not essential for photosynthetic competence but functions as a light harvesting assembly, primarily for photosystem II (Thornber 1986). The LHCII complex alone accounts for about half of the total membrane protein and chlorophyll content and therefore is of special importance from the standpoint of the thylakoid membrane structure. Apart from its function as an antenna that collects light energy, this complex regulates the transfer of excitation energy to the reaction centers of PSII and PSI, depending on the phosphorylation of its apoprotein (Bennet et al. 1984, S ta ehelin 1986). The complex also mediates the interaction of thylakoid membranes, which leads to the formation of stacks of membrane vesicles - the chloroplast grana (Staehelin 1986). A three-dimensional map of this complex shows that the LHCII is a highly asymmetric transmembrane protein composed of three structurally equivalent monomers. A large surface area exposed on one side of the oligomeric complex suggests a functional role in membrane interactions (Kühlbrandt et al. 1983, Kühlbrandt 1984, Li 1985). The ability of LHCII from widely different plant species to form such oligomeric supramolecular arrays suggests that this structure is of general significance.

Several different methods have been used to obtain pure LHCII preparations. In the primary steps of purification, all of them utilize detergents such as digitonin, SDS or Triton X-100. Final steps of purification were made with preparative polyacrylamide gel electrophoresis (Picaud et al. 1982), sucrose gradient centrifugation (Burke et al. 1978, Foyer and Hall 1979, Mullet and Arntzen 1980), column chromatography (Dunkley and Anderson 1979, Thornber and Thornber 1980, Süss 1983), isoelectrofocusing (Satoh 1979b, Larkum and Anderson 1982) or phase-partition systems (Albertsson and Andersson 1981). Recently, the simple and rapid "method of successive precipitations", the results of which was reproducible isolation of large quantities of highly purified LHCII from various plants, has been developed by Krupa et al. (1987a). Isolated LHCII preparations, irrespective of the procedure used, usually contain 2-4 polypeptides with apparent molecular weights in the range of $26-29 \mathrm{kD}$. A low chlorophyll a/b ratio of $1.0-1.2$ is very characteristic for this complex.

As was mentioned in the previous chapters, analyses of the acyl lipid composition of isolated photosynthetic supramolecular complexes are, in fact, not very common. From the data summarized in Table 4 it can be clearly seen that the isolated LHCII preparations are specifically enriched with PG. Moreover, it is well known that this phospholipid contains a unique fatty acid, trans- $\Delta^{3}$-hexadecenoic acid (trans-16:1) which is specifically bound to PG molecules in position $s n-2$ only (D u bacq and Tremolieres 1983). From many recent works it also appears that it is the compound which plays a role in association of the protein subunits of the LHCII oligomer (Tremolieres et al. 1982, 1984, Huner et al. 1987a, b, Król et al. 1987, Krupa et al. 1987a, Williams et al. 1987, Krupa 1988). The investigations concerning the role of PG containing trans- 16:1 acid in the 
Table 4

A comparison of the acyl lipid composition of LHCII preparations isolated by various methods

\begin{tabular}{|c|c|c|c|c|c|c|c|c|c|}
\hline \multirow{2}{*}{$\frac{\text { Acyl lipid }}{\text { MGDG }}$} & \multicolumn{9}{|c|}{$\%$ Of total content } \\
\hline & 34.1 & 52.8 & 33.3 & 51.0 & 58.4 & 48.8 & 51.9 & 28.3 & 34.4 \\
\hline DGDG & 29.1 & 26.1 & 29.0 & 28.0 & 15.5 & 13.4 & 29.4 & 25.3 & 28.4 \\
\hline SQDG & 12.8 & 14.6 & $9.5^{*}$ & 6.0 & $3.6^{*}$ & 13.4 & 2.3 & 6.1 & 5.6 \\
\hline PG & 15.7 & 6.5 & 28.2 & 15.0 & 5.5 & 21.2 & 12.6 & 33.3 & 29.7 \\
\hline PC & 6.5 & - & - & - & - & 3.1 & 3.9 & 7.1 & 1.9 \\
\hline PI & 1.7 & - & - & - & - & - & - & - & - \\
\hline \multirow[t]{2}{*}{ Source } & spinach & spinach & tobacco & maize & tobacco & tobacco & spinach & rye & radish \\
\hline & (1) & (2) & (3) & (4) & (5) & (6) & & (8) & $\begin{array}{c}\text { cotyledons } \\
\text { (9) }\end{array}$ \\
\hline
\end{tabular}

* - SQDG + PC
(1) - Rawyler et al. 1980,
(2) - Ryrie et al. 1980,
$(3,5)$ - Tremolieres et al. 1981, 1982,
(4) - Selstam 1981,
(6) - Remy et al. 1982,
(7) - Tuquet et al. 1984,
(8) - Krupa et al. 1987a,
(9) - Krupa 1988. 
supramolecular structure of LH( II can be divided into two gr ups. The first one deals with the in vitro factors modifying the lipid and fatty acid composition of LHCII using lipolytic enzymes (Tremolieres et al. 1982, Krupa 1984a, b, Huner et al. 1987b, Krupa et al. 1987a) or using artificial liposomes specifically enriched with trans-16:1 acid (Rem y et al. 1982, 1984a, b, Tremolieres et al. 1984). The second group refers to the in vivo studies on the effect of environmental conditions (e.g. light, herbicides, low temperature stress, heavy metals) or specific mutations (lack of trans-16:1 acid) on the structure and function of this chl-protein complex (Lemoine et al. 1982, Leech and Walton 1983, McCourt et al. 1985, Huner et al. 1987a, b, Król et al. 1987, Krupa et al. 1987a, b, Krupa 1988, Maroc et al. 1987, Williams et al. 1987). The effect of some in vivo and in vitro factors (low temperature stress, heavy metal treatment, lipolytic enzymes) affecting the content of trans-16:1 acid in the PG pool of isolated LHCII and its relationship to the level of LHCII oligomeric form is shown in Table 5. The results reported in this chapter and summarized in Table 5 unequivocally

Table 5

The relations between trans- $\Delta^{3}$-hexadecenoic acid and the LHCII oligomer content in different environmental in vivo and in vitro conditions

\begin{tabular}{|l|c|c|}
\hline \multicolumn{1}{|c|}{ Conditions } & $\begin{array}{c}\text { Trans-16:1/16:0 } \\
\text { ratio }\end{array}$ & $\begin{array}{c}\text { Monomer/oli- } \\
\text { gomer ratio }\end{array}$ \\
\hline $\begin{array}{l}\text { Low temperature stress }{ }^{1} \\
\text { control }\left(+20^{\circ} \mathrm{C}\right)\end{array}$ & 1.48 & 0.50 \\
treated $\left(+5^{\circ} \mathrm{C}\right)$ & 0.32 & 0.80 \\
Heavy metal stress ${ }^{2}$ & 2.21 & 1.84 \\
control & 0.38 & 4.71 \\
cadmium & & \\
Lipolytic enzymes & & \\
control & 1.60 & 0.40 \\
phospholipase $\mathrm{A}_{2}$ & $-{ }^{*}$ & 1.65 \\
\hline
\end{tabular}

* - the complete hydrolysis of PG,

1 - rye (Huner et al. 1987b, Krupa et al. 1987a),

2 - radish cotyledons (Krupa et al. 1987b, Krupa 1988)

${ }^{3}$ - isolated rye LHCII (Huner et al. 1987b, Krupa et al. 1987a),

indicate a positive correlation between the level of trans-16:1 acid and the oligomerization of LHCII. The correlation coefficients $\left(R_{x, y}\right)$ calculated for the relation between trans-16:1 and oligomer content reached values from 0.9644 (Huner et al. 1987a) to 0.9828 (Krupa 1988). This supports the hypothesis about the role of this fatty acid in the supramolecular organization of LHCII even if some authors' opinions are not quite clear on that point. Moreover, the results quoted here revealed that regardless of the kind of environmental stress, its final effect on LHCII was related to the characteristic shift in the trans-16:1 
acid content towards the saturated palmitic acid (16:0) with the concomitant decrease in the oligomer/monomer ratio (Table 5). The primary mechanism generating this shift still remains unknown, although the inhibition of palmitate desaturase might be considered.

From the very beginning of this chapter our attention has been focused on the role of PG and trans-16:1 acid in the structure and function of the LHCII complex. However, this complex also contains other acyl lipids of which MGDG may as well be of some importance for the functioning of LHCII. Though previously questioned as an integral component of LHCII ( $\mathrm{Heinz}$ and Siefermann-Harms 1981), it now seems to play some role in the energy transfer from LHCII to the photosystems (Siefermann-Harms et al. 1982). The importance of MGDG and DGDG, besides PG, for the proper organization and function of LHCII has also been underlined repeatedly by Krupa (Krupa 1983, 1984a, b, Krupa et al. 1987a) on the basis of experiments with the use of some lipolytic enzymes e.g. galactolipase, acting on thylakoid membranes, chl-protein complexes and isolated and purified LHCII. Although MGDG and DGDG appear not to be intimately related to the stabilization of oligomeric LHCII, they may be involved in the stabilization of chlorophyll-protein interactions since hydrolysis of the galactolipid pool of LHCII resulted in a significant increase of free pigments disjoined from the complex (Krupa et al. 1987a). The hypothesis of Rosenberg (1967) that galactolipids, because of their high content of polyunsaturated fatty acids (especially linolenic acid), would ensure the proper arrangement of chlorophyll molecules within chl-protein complexes should be reminded at this point.

It must be emphasized that probably not only trans-16:1-containing PG is involved in the stabilization of the oligomeric form of LHCII. It was shown during experiments on the effect of lipolytic enzymes on the structure of isolated LHCII that even after total hydrolysis of almost all, except one, acyl lipids (MGDG, DGDG, PG, PC) present in this complex - a small but considerable amount of LHCII in oligomeric form still remains stable (K r u pa et al. 1987a). The exception mentioned above was SQDG, the only lipid hydrolyzed to a very low degree by the enzymes used about $90 \%$ left in LHCII preparations). Thus, the possible involvement of this strongly anionic lipid as a factor assisting PG containing trans-16:1 acid in the stabilization of the LHCII oligomer requires more detailed studies.

\section{CONCLUDING REMARKS}

In light of the studies presented in this review and concerning more or less directly the role of acyl lipids in the structure and function of the supramolecular chl-protein complexes of photosystems, it would be premature to propose a definite picture of such relationships. The only role that seems to be well documented and proved is that of trans-16:1-containing PG in oligomerization of the LHCII complex, although it should be definitely determined whether this specific form of $\mathrm{PG}$ is involved in the formation of the 
LHCII oligomer or its stabilization, or both. It is too early to connect unambiguously the presence of a specific lipid class with the expression of a specific function of chl-protein complexes related to the reaction centers of PSI and PSII. However, some serious indications exist and they must be extensively investigated in the nearest future. Despite all the questionable cases mentioned above, in this author's opinion it is beyond doubt that acyl lipids are integral components of photosystem supramolecular complexes, regulating their structure and function.

It should be emphasized here that there is still a number of people questioning such close coexistence and interrelations between lipids and protein complexes in the thylakoid membranes. To them I would like to dedicate an excerpt from Francis Clifford's "The naked runner": "According to the theory of aerodynamics, and as may be readily demonstrated by means of a wind tunnel, the bumble-bee is unable to fly. This is because the size, weight and shape of his body in relation to the total wing span makes flight impossible. But the bumble-bee, being ignorant of these scientific facts and possessing considerable determination, does fly - and makes a little honey, too".

\section{Acknowledgments}

I dedicate this review to the memory of my Father. This work was supported by the project CPBP 05.02 .

\section{REFERENCES}

Albertsson P. A., Andersson B., 1981. Separation of membrane components by partition in detergent-containing polymer phase systems. Isolation of the light harvesting chlorophyll a/b protein. J. Chromatogr. 215: 131-141.

Anders on J. M., 1975. The molecular organization of chloroplast thylakoids. Biochim. Biophys. Acta 416: 191-235.

Bassi R., Simpson D., 1987. Chlorophyll-protein complexes of barley photosystem I. Eur. J. Biochem. 163: 221-230.

Bennet J., Williams R., Jones E., 1984. Chlorophyll-protein complexes of higher plants: protein phosphorylation and preparation of monoclonal antibodies. In: Advances in photosynthesis research. Sybesma C. (ed.). Martinus Nijhoff/Dr W. Junk Publishers, The Hague-Boston-Lancaster. V. III, pp. 99-106.

Berthold D. A., Babcock G. T., Yocum C. F., 1981. A highly resolved, oxygen-evolving photosystem II preparation from spinach thylakoid membranes. FEBS Lett. 134: 231-234.

Burke J. J., Dit to C. L., Arntzen C. J., 1978. Involvement of the light harvesting complex in cation regulation of excitation energy distribution in chloroplasts. Arch. Biochem. Biophys. 187: 252-263.

C a m m E. L., Green B. R., 1980. Fractionation of thylakoid membranes with the nonionic detergent octyl- $\beta$-D-glucopyranoside. Resolution of chlorophyll-protein complex II into two chlorophyll-protein complexes. Plant Physiol. 66: 428-432.

Chapman D. J., De-Felice J., Barber J., 1984. Lipids at sites of quinone and herbicide interaction with the photosystem two pigment-protein complex of chloroplast thylakoids. In: Structure, function and metabolism of plant lipids. Siegenthaler P. A., Eichenberger W. (eds.). Elsevier Science Publishers, Amsterdam-New York-Oxford, pp. 457-464.

Dubacq J. P., Tremolieres A., 1983. Occurrence and function of phosphatidylglycerol 
containing $\Delta^{3}$-trans-hexadecenoic acid in photosynthetic lamellae. Physiol. Vég. 21: 293-312.

Dunkley P. R., Anderson J. M., 1979. Isolation of the light-harvesting chlorophyll a/b protein complex from thylakoid membranes of barley by adsorption chromatography on controlled-pore glass. Arch. Biochem. Biophys. 193: 469-477.

Foyer C. H., Hall D.O., 1979. A rapid procedure for the preparation of light-harvesting chlorophyll a/b protein complex. An assessment of its manganese content. FEBS Lett. 101: 324-328.

Ghanotakis D. F., Yocum C. F., 1986. Purification and properties of an oxygen-evolving reaction complex from photosystem II membranes. FEBS Lett. 197: 244-248.

Giroud C., Siegenthaler P. A., 1984. Study of the distribution of phospholipids in prothylakoids and thylakoids from oat and spinach. In: Structure, function and metabolism of plant lipids. Siegenthaler P. A., Eichenberger W. (eds.). Elsevier Science Publishers, Amsterdam-New York-Oxford, pp. 413-416.

Gounaris K., Barber J., 1985. Isolation and characterization of a photosystem II reaction centre lipoprotein complex. FEBS Lett. 188: 68-72.

Gounaris K., Whitford D., Barber J., 1983. The effect of thylakoid lipids on an oxygen-evolving photosystem II preparation. FEBS Lett. 163: 230-234.

Gounaris K., Whitford D., Barber J., 1984a. The effect of polar thylakoid lipids on oxygen evolution. In: Advances in photosynthesis research. Sybesma C. (ed.). Martinus Nijhoff/Dr W. Junk Publishers, The Hague-Boston-Lancaster, V.III, pp. 107-110.

Gounaris K., Pick U., Barber J., 1984b. The effect of thylakoid lipids on enzymatic activity and ultrastructure of membrane protein complexes. In: Structure, function and metabolism of plant lipids. Siegenthaler P. A., Eichenberger W. (eds.). Elsevier Science Publishers, Amsterdam-New York-Oxford, pp. 451-455.

Guillot-Salomon T., Tuquet C., Farineau N., Farineau J., Signol M., 1982. Lipoprotein association in chlorophyll containing complexes isolated by non-ionic detergents. In: Biochemistry and metabolism of plant lipids. Wintermans J. F. G. M., Kuiper P. J. C. (eds.). Elsevier Biomedical Press, Amsterdam-New York-Oxford, pp. 373-376.

Hayden D. B., Hopkins W. G., 1977. A second distinct chlorophyll a-protein complex in maize mesophyll chloroplasts. Can J. Bot. 56: 2525-2529.

Heinz E., Siefermann-Harms D., 1981. Are galactolipids integral components of the chlorophyll-protein complexes in spinach thylakoids? FEBS Lett. 124: 105-111.

Henry L. E. A., Siegenthaler P. A., 1981. Does the initial state of thylakoids influence photochemical activities, lipid transformations and characteristics of the chlorophyll/ /protein complexes? In: Photosynthesis. Structure and molecular organization of the photosynthetic apparatus. Akoyunoglou G. (ed.). Balaban International Science Services, Philadelphia, V.III, pp. 567-576.

Henry L. E. A., Strasser R. J. Siegenthaler P. A., 1982. Alteration in the lipid composition of thylakoids induced by aging and its effect on thylakoid structure. Plant Physiol. 69: 531-536.

Henry L. E. A., Mфller B. L., Mikkelsen J. D., 1984. Cytochromes, pigments and acyl lipids of photosystem I and photosystem II. In: Structure, function and metabolism of plant lipids. Siegenthaler P. A., Eichenberger W. (eds.). Elsevier Science Publishers, Amsterdam-New York-Oxford, pp. 397-400.

Huner N. P. A., Kró! M., Williams J. P., Maissan E., Low P., Roberts D., Th o m p s on J. E., 1987a. Low temperature development induces a specific decrease in trans- $\Delta^{3}$-hexadecenoic acid content which influences LHCII organization. Plant Physiol. 84: 12-18.

Huner N. P. A., Krupa Z., Williams J. P., Maissan E., 1987b. Phosphatidylglycerol content and composition influence in vitro oligomerization of purified LHCII from winter rye. In: Progress in photosynthesis research. Biggins J. (ed.). Martinus Nijhoff Publishers, Dordrecht, V.IV, pp 119-122.

Ikeuchi M., Yuasa M., Inoue Y., 1985. Simple and discrete isolation of an $\mathrm{O}_{2}$-evolving PSII reaction center complex retaining $\mathrm{Mn}$ and the extrinsic $33 \mathrm{kDa}$ protein. FEBS Lett. 185: 316-322. 
Król M., Huner N. P. A., Williams J. P., Maissan E., 1987. 3-Transhexadecenoic acid content and LHCII organization during chloroplast biogenesis at low temperature. In: Progress in photosynthesis research. Biggins J. (ed.). Martinus Nijhoff Publishers, Dordrecht, V. IV, pp. 123-125.

Krupa Z., 1982. The action of lipases on chloroplast membranes. I. The release of plastocyanin from galactolipase-treated thylakoid membranes. Photosynthesis Res. 3: 95-104.

K rupa Z., 1983. The action of lipases on chloroplast membranes. II. Polypeptide patterns of bean galactolipase- and phospholipase $\mathrm{A}_{2}$-treated thylakoid membranes. Photosynthesis Res. 4: 229-239.

Krupa Z., 1984a. Changes in chlorophyll-protein complexes of bean galactolipase- or phospholipase $\mathrm{A}_{2}, \mathrm{C}$ and D-treated thylakoid membranes. In: Advances in photosynthesis research. Sybesma C. (ed.). Martinus Nijhoff/Dr W. Junk Publishers. The Hague-Boston-Lancaster, V.III, pp. 119-121.

K rupa Z., 1984b. The action of lipases on chloroplast membranes. III. The effect of lipid hydrolysis on chlorophyll-protein complexes in thylakoid membranes. Photosynthesis Res. 5: 177-184.

Krupa Z., 1988. Cadmium-induced changes in the composition and structure of the light-harvesting chlorophyll a/b protein complex II in radish cotyledons. Physiol. Plant. 73: 518-524.

Krupa Z., Baszyński T., 1975. Requirement of galactolipids for photosystem I activity in lyophilized spinach chloroplasts. Biochim. Biophys. Acta 408: 26-34.

Krupa Z., Baszyński T., 1977. Participation of sulphoquinovosyl diacylglycerol in the reconstitution of photosystem I activity of heptane-extracted chloroplasts. Bull. Acad. Pol. Sci. 25: 409-413.

Krupa Z., Baszyński T., 1985. Effects of cadmium on the acyl lipid content and fatty acid composition in thylakoid membranes isolated from tomato leaves. Acta Physiol. Plant. 7: 55-64.

Krupa Z., Huner N. P. A., Williams J. P., Maissan E., James D. R., 1987a. Development at cold-hardening temperatures. The structure and composition of purified rye light harvesting complex II. Plant Physiol. 84: 19-24.

Krupa Z., Skórzyńska E., Maksymiec W., Baszyński T., 1987b. Effect of cadmium treatment on the photosynthetic apparatus and its photochemical activities in greening radish seedlings. Photosynthetica 21: 156-164.

K ühlbrandt W., Thaler T. H., Wehrli E., 1983. The structure of membrane crystals of the light-harvesting chlorophyll a/b protein complex. J. Cell. Biol. 96: 1414-1424.

Kühlbrandt W., 1984. Three-dimensional structure of the light-harvesting chlorophyll a/b protein complex. Nature 307: 478-480.

Lam E., Baltimore B., Ortiz W., Malkin R., 1984. Fractionation of an oxygen-evolving Photosystem II preparation: characterization of the light-harvesting antennae and reaction center components. Photobiochem. Photobiophys. 7: 69-76.

Larkum A. W. D., Anderson J. M., 1982. The reconstitution of photosystem II protein complex, P-700-chlorophyll a-protein complex and light-harvesting chlorophyll a/b-protein. Biochim. Biophys. Acta 679: 410-421.

Leech R. M., Walton C. A., 1983. Modification of fatty acid composition during chloroplast ontogeny and the effects on thylakoid appression and primary photochemistry. In: Biosynthesis and function of plant lipids. Thomson W. W., Mudd J. B., Gibbs M. (eds.). Waverley Press, Baltimore, pp. 56-80.

Lemoine Y., Dubacq J. P., Zabulon G., 1982. Changes in the light-harvesting capacities and $\Delta^{3}$-trans-hexadecenoic acid content in dark- and light-grown Picea abies. Physiol. Vég. 20: 487-503.

Li J., 1985. Light-harvesting chlorophyll a/b-protein: Three-dimensional structure of a reconstituted membrane lattice in negative stain. Proc. Natl. Acad. Sci. USA 82: 386-390.

Maroc J., Tremolieres A., Garnier J., Guyon D., 1987. Oligomeric form of the light-harvesting chlorophyll $\mathrm{a}+\mathrm{b}$-protein complex CPII, phosphatidylglycerol, $\Delta$-transhexadecenoic acid and energy transfer in Chlamydomonas reinhardtii, wild type and mutants. Biochim. Biophys. Acta 893: 91-99. 
McCourt P., Browse J. Watson J., Arntzen C. J., Somerville C., 1985. Analysis of photosynthetic antenna function in a mutant of Arabidopsis thaliana (L.) lacking trans-hexadecenoic acid. Plant. Physiol. 78: 853-858.

Menke W., Radunz A., Schmid G. H, Koenig F., Hirtz R. D., 1976. Intermolecular interactions of polypeptides and lipids in the thylakoid mebrane. Z. Naturforsch. 31c: 436-444.

Mullet J. E., Arntzen C. J., 1980. Simulation of grana stacking in a model membrane system. Mediation by purified light harvesting pigment-protein complex from chloroplasts. Biochim. Biophys. Acta 589: 100-117.

Mullet J. E., Burke J. J., Arntzen C. J., 1980a. Chlorophyll proteins of photosystem I. Plant Physiol 65: 814-822.

Mullet J. E., Burke J. J., Arntzen C. J., 1980b. A developmental study of photosystem I peripheral chlorophyll proteins. Plant Physiol. 65: 823-827.

Murphy D. J., 1984. The role of acyl lipids in the reconstitution of photosynthetic membrane functions. In: Structure, function and metabolism of plant lipids. Siegenthaler P. A., Eichenberger W. (eds.). Elsevier Science Publishers, Amsterdam-New York-Oxford, pp. 465-469.

Murphy D. J., Knowles P., 1984. Phospholipid-protein interactions in photosynthetic membranes. An electron spin resonance study. In: Structure, function and metabolism of plant lipids. Siegenthaler P. A., Eichenbereger W. (eds.). Elsevier Science Publishers, Amsterdam-New York-Oxford, pp. 425-428.

Murphy D. J., Woodrow I. E., 1984. The role of acyl lipids in the function and molecular organization of photosynthetic membranes. In: Advances in photosynthesis research. Sybesma C. (ed.). Martinus Nijhoff/Dr W. Junk Publishers, The Hauge-Boston-Lancaster, V. III, pp. 111-114.

Noben J. P., Valcke R., van Poucke M., Clijsters H., 1983. Reinvestigation of the chlorophyll distribution among the chlorophyll-proteins and chlorophyll-protein complexes of Hordeum vulgare L. Photosynthesis Res. 4: 129-136.

Picaud A., Acker S., Duranton J., 1982. A single step separation of PS1, PS2 and chlorophyll-antenna particles from spinach chloroplasts. Photosynthesis Res. 3: 203-213.

Radunz A., 1980. Binding of antibodies onto the thylakoid membrane. VI. Asymmetric distribution of lipids and proteins in the thylakoid membrane $Z$. Naturforsch. 35c: 1024-1031.

Radunz A., 1981. Application of antibodies in the analysis of structural configuration of thylakoid membranes. Ber. Deutsch. Bot. Ges. 94: 477-489.

Radunz A., 1984. Serological investigations on the function of phospholipids in the thylakoid membrane. In: Advances in photosynthesis research. Sybesma C. (ed.). Martinus Nijhoff/Dr W. Junk Publishers, The Hague-Boston-Lancaster, V.III, pp. 151-154.

Radunz A., Berzborn R., 1970. Antibodies against sulphoquinovosyldiacylglycerol and their reactions with chloroplasts $Z$. Naturforsch. 25b: 412-419.

Radunz A., Bader K. P., Schmid G. H., 1984a. Influence of antisera to sulfoquinovosyl diglyceride and to $\beta$-sitosterol on the photosynthetic electron transport in chloroplasts from higher plants. In: Structure, function and metabolism of plant lipids. Siegenthaler P. A., Eichenberger W. (eds.). Elsevier Science Publishers, Amsterdam-New York-Oxford, pp. 479-484.

Radunz A., Bader K. P., Schmid G. H., 1984b. Serological investigations on the function of galactolipids in the thylakoid membrane. Z. Pflanzenphysiol. 114: 227-231.

Rawyler A., Henry L. E. A., Siegenthaler P. A., 1980. Acyl and pigment lipid composition of two chlorophyll-proteins. Carlsberg Res. Commun. 45: 443-451.

Rawyler A., Siegenthaler P. A., 1980. Function and distribution of phospholipids in spinach thylakoid membranes as revealed by phoshpolipase $A_{2}$ treatment. In: Biogenesis and function of plant lipids. Mazliak P., Benveniste P., Costes C., Douce R. (eds.). Elsevier/North Holland Biomedical Press, Amsterdam-New York-Oxford, pp. 117-120.

Rawyler A., Siegenthaler P. A., 1981a. Regulation of photosystem I electron flow activity by 
phosphatidylglycerol in thylakoid membranes as revealed by phospholipase treatment. Biochim. Biophys. Acta 638: 30-39.

Rawyler A., Siegenthaler P. A., 1981b. Transmembrane distribution of phospholipids and their involvement in electron transport, as revealed by phospholipase $A_{2}$ treatment of spinach thylakoids. Biochim. Biophys. Acta 635: 348-358.

Rawyler A., Siegenthaler P. A., 1984. Localization of monogalactosyldiglyceride and digalactosyldiglyceride in spinach thylakoid membranes. In: Structure, function and metabolism of plant lipids. Siegenthaler P. A., Eichenberger W. (eds.). Elsevier Science Publishers, Amsterdam-New York-Oxford, pp. 409-412.

Rawyler A., Siegenthaler P. A., 1985. Transversal localization of monogalactosyldiacylglycerol and digalactosyldiacylglycerol in spinach thylakoid membranes. Biochim. Biophys. Acta 815: 287-298.

Rawyler A., Unitt M. D., Giroud C., Davies H., Mayor J. P., Harwood J. L., Siegenthaler P. A., 1987. The transmembrane distribution of galactolipids in chloroplast thylakoids is universal in a wide variety of temperate climate plants. Photosynthesis Res. 11: 3-13.

Remy R., Ambard-Bretteville F., Dubacq J. P., Tremolieres A., 1984a. Lipid-induced transformations of the monomeric to oligomeric forms of LHCP. In: Advances in photosynthesis research. Sybesma C. (ed.). Martinus Nijhoff/Dr W. Junk Publishers. The Hague-Boston-Lancaster, V.II, pp. 133-136.

Remy R., Tremolieres A., Ambard-Bretteville F., 1984b. Formation of oligomeric light-harvesting chlorophyll $\mathrm{a} / \mathrm{b}$ protein by interactions between its monomeric form and liposomes. Photobiochem. Photobiophys. 7: 267-276.

Remy R., Tremolieres A., Duval J. C., Ambard-Bretteville F., Dubacq J. P., 1982. Study of the supramolecular organization of light harvesting chlorophyll protein (LHCP). Conversion of the oligomeric form into the monomeric one by phospholipase $A_{2}$ and reconstitution with liposomes. FEBS Lett. 137: 271-275.

Rosenberg A., 1967. Galactosyl diglycerides: Their possible function in Euglena chloroplasts. Science 157: 1191-1196.

Ryrie J., Anderson J. M., Goodchild D. J., 1980. The role of light harvesting chlorophyll a/b protein complex in chloroplast membrane stacking. Cation-induced aggregation of reconstituted proteoliposomes. J. Biochem. 107: 345-354.

Satoh K., 1979a. Polypeptide composition of the purified photosystem II pigment-protein complex from spinach. Biochim. Biophys. Acta 546: 84-92.

Satoh K., 1979b. Properties of light harvesting chlorophyll a/b protein and photosystem I chlorophyll a-protein purified from digitonin extracts of spinach chloroplasts by isoelectrofocusing. Plant Cell Physiol. 20: 499-512.

Satoh K., Ohno T., Katoh S., 1985. An oxygen-evolving complex with a single subunit structure - "a water-plastoquinone oxidoreductase" - from the thermophilic cyanobacterium Synechococcus sp. FEBS Lett. 180: 326-330.

Schmid G. H., Menke W., Radunz A., Koenig F., 1978. Polypeptides of the thylakoid membrane and their functional characterization. Z $Z$. Naturforsch. 33c: 723-730.

Selstam E., 1981. Lipids of the light-harvesting chlorophyll- protein complexes. In: Photosynthesis. Structure and molecular organization of the photosynthetic apparatus. Akoyunoglou G. (ed.). Balaban International Science Services, Philadelphia, V.III, pp. 631-634.

Siefermann-Harms D., Ross J. W., Kaneshiro K. H., Yamamoto H. Y., 1982. Reconstitution by monogalactosyldiacylglycerol of energy transfer from light-harvesting chlorophyll a/b-protein complex to the photosystems in Triton X-100-solubilized thylakoids. FEBS Lett. 149: 191-196.

Siegenthaler P. A., 1982. Transmembrane distribution and function of lipids in spinach thylakoid membranes: rationale of the enzymatic modification method. In: Biochemistry and metabolism of plant lipids. Wintermans J. F. G. M., Kuiper P. J. C. (eds.). Elservier Biomedical Press, Amsterdam-New York-Oxford, pp. 351-358. 
Siegenthaler P. A., Giroud C., 1986. Transversal distribution of phospholipids in prothylakoid and thylakoid membranes from oat. FEBS Lett. 201: 215-220.

Siegenthaler P. A., Rawyler A., 1986. Acyl lipids in thylakoid membranes. Distribution and involvement in photosynthetic functions. In: Encyclopedia of plant physiology - New Series. Staehelin L. A., Arntzen C. J. (eds.). Springer Verlag, Berlin-Heidelberg-New York-Tokyo, V.XIX, pp. 693-705.

Siegenthaler P. A., Smutny J., Rawyler A., 1987. Involvement of distinct populations of phosphatidylglycerol and phosphatidylcholine in photosynthetic electron flow. Biochim. Biophys. Acta 891: 85-93.

St a ehe lin L. A., 1986. Chloroplast structure and supramolecular organization of photosynthetic membranes. In: Encyclopedia of plant physiology - New Series. Staehelin L. A., Arntzen C.

J. (eds.). Springer Verlag, Berlin-Heidelberg-New York-Tokyo, V. XIX, pp. 1-84.

Süss K. H., 1983. A new isolation method and properties of the light harvesting chlorophyll a/b protein complex of higher plants. Photobiochem. Photobiophys. 5: 317-324.

Thomas P. G., Quinn P. J., Williams W. P., 1984. The role of nonbilayer forming lipids in thylakoid membrane stability. In: Structure, function and metabolism of plant lipids. Siegenthaler P. A., Eichenberger W. (eds.). Elsevier Science Publishers, Amsterdam-New York-Oxford, pp. 389-392.

Thornber J. P., 1986. Biochemical organization and structure of pigment-proteins of photosynthetic organisms. In: Encyclopedia of plant physiology - New Series. Staehelin L. A., Arntzen C. J. (eds.). Springer Verlag, Berlin-Heidelberg-New York-Tokyo, V.XIX, pp. 98-142.

Thornber J. P., Thornber J. M., 1980. The light harvesting chlorophyll a/b protein. In: Methods in enzymology. Colowick S. P., Kaplan N. O. (eds.). Academic Press, New York-London-Toronto-Sydney-San Francisco, V. 69c, pp. 150-154.

Tremolieres. A., Dubacq J. P., Ambard-Bretteville F., Remy R., 1981. Lipid composition of chlorophyll protein complexes. FEBS Lett. 130: 27-31.

Tremolieres A., Dubacq J. P., Duval J. C., Lemoine Y., Remy R., 1982. Role of phosphatidylglycerol containing trans-hexadecenoic acid in oligomeric organization of the light-harvesting chlorophyll protein (LHCP). In: Biochemistry and metabolism of plant lipids. Wintermans J. F. G. M., Kuiper P. J. C. (eds.). Elsevier Biomedical Press, Amsterdam-New York-Oxford, pp. 369-372.

Tremolieres A., Remy R., Ambard-Bretteville F., Dubacq J. P., 1984. Role of phosphatidylglycerol containing trans-hexadecenoate in the suprmolecular organization of the dimeric chlorophyll $\mathrm{a} / \mathrm{b}$ protein complex. In: Structure, function and metabolism of plant lipids. Siegenthaler P. A., Eichenberger W. (eds.). Elsevier Science Publishers, Amsterdam-New York-Tokyo, pp. 429-432.

Tuquet C., Guillot-Salom on T., Farineau N., 1984. Involvement of phosphatidylglycerol containing trans- $\Delta^{3}$-hexadecenoic acid in photosystem II activity in spinach chloroplasts. In: Structure, function and metabolism of plant lipids. Siegenthaler P. A., Eichenberger W. (eds.). Elsevier Science Publishers, Amsterdam-New York-Tokyo, pp. 471-474.

Unitt M. D., Harwood J. L., 1982. Lipid topography of thylakoid membranes. In: Biochemistry and metabolism of plant lipids. Wintermans J. F. G. M., Kuiper P. J. C. (eds.). Elsevier Biomedical Press, Amsterdam-New York-Oxford, pp. 359-362.

Vierling E., Alberte R. S., 1983. P $_{700}$ chlorophyll a-protein. Purification, characterization and antibody preparation. Plant Physiol. 72: 625-633.

Waldron J. C., Anderson J. M., 1979. Chlorophyll-protein complexes from thylakoids of a mutant barley lacking chlorophyll b. Eur. J. Biochem. 102: 357-362.

Williams J. P., Huner N. P. A., Król M., Maissan E., Low P. S., Roberts D., Thompson J. E., 1987. In vivo low temperature-induced decrease in 3-trans-hexadecenoic acid influences oligomerization of LHCII. In: Progress in photosynthesis research. Biggins J. (ed.). Martinus Nijhoff Publishers, Dordrecht, V.IV, pp. 127-130. 
Lipidy acylowe $w$ supramolekularnych kompleksach chlorofilowo-bialkowych fotoukladów - izolacyjne artefakty czy integralne skladniki regulujące strukture i funkcje??

Streszczenie

Nie wyjaśniono dotychczas dokładnie natury oddziaływań między kompleksami chlorofilowo-białkowymi fotoukładów i lipidami acylowymi błon tylakoidowych. Analizy składu lipidowego tych kompleksów wskazują na to, że lipidy acylowe są ich integralnymi składnikami. Przedyskutowano wyniki najnowszych badań dotyczących relacji między określonymi składnikami lipidowymi kompleksów chlorofilowo-białkowych, a ich strukturą i funkcją. Szczegółowo omówiono rolę kwasu trans- $\Delta^{3}$-heksadecenowego w oligomeryzacji kompleksu antenowego II fotoukładu (LHCII) - najlepiej dotychczas poznany przykład wzajemnych oddziaływań lipid-białko w błonach tylakoidowych. 